\title{
THE DON COSSACKS AT THE POLISH FRONT IN 1919
}

\author{
Andrey V. Venkov \\ Southern Scientific Center of Russian Academy of Sciences, Rostov-on-Don, Russian Federation
}

\begin{abstract}
During the civil war in the Don region in early 1919, a considerable part of the Cossacks of the white Don army lost faith in the regime of General Krasnov and went home. But they found themselves on the territory affected by the policy of "decossackization". When the white troops began the offensive again, the Bolsheviks decided to mobilize these Cossacks, before the whites would mobilize them. The mobilization was covered by the authority of F. K. Mironov, a very famous red Cossack, former Cossack officer, who commanded the Soviet Belarusian-Lithuanian army. More than 5 thousand people were mobilized. The part of mobilized Cossacks was sent to the Belarusian-Lithuanian army, where they created two Cossack regiments. However, F. K. Mironov got a new appointment by that time. The Cossacks remaining in the ranks of the Belarusian-Lithuanian army, were in unusual and difficult conditions. During the fighting they were in Jewish settlements. When the Poles began their offensive, the most efficient part of the mobilized Cossacks gathered in the $1^{\text {st }}$ regiment, went over to the Polish side. The $2^{\text {nd }}$ Cossack regiment was disarmed by the Soviet command and sent to Saransk available to F. K. Mironov. The Don corps, generated by F. K. Mironov in Saransk from another part of the mobilized Cossacks, rebelled in August 1919. Experience has shown that during the development of red Cossack units Bolsheviks had to rely on a few volunteers and defectors. Forcibly mobilized Cossacks were unreliable and turned to the enemy.

Key words: Cossacks, Poles, F. K. Mironov, mobilization, Belarusian-Lithuanian army.

Citation. Venkov A.V. The Don Cossacks at the Polish Front in 1919. Vestnik Volgogradskogo gosudarstvennogo universiteta. Serija 4, Istorija. Regionovedenie. Mezhdunarodnye otnoshenija [Science Journal of Volgograd State University. History. Area Studies. International Relations], 2017, vol. 22, no. 6, pp. 99-109. (in Russian). DOI: https://doi.org/10.15688/jvolsu4.2017.6.10
\end{abstract}

УДК 94(47).084.3

Дата поступления статьи: 05.09.2017

ББК 63.3(2)

Дата принятия статьи: 26.09.2017

\section{ДОНСКИЕ КАЗАКИ НА ПОЛЬСКОМ ФРОНТЕ В 1919 ГОДУ}

\author{
Андрей Вадимович Венков \\ Южный научный центр Российской академии наук, г. Ростов-на-Дону, Российская Федерация
}

\begin{abstract}
Аннотация. Во время гражданской войны на Дону, в начале 1919 г., значительная часть казаков из белой Донской армии, разуверившись в режиме генерала Краснова, разошлась по домам. Они оказались на территории, подвергшейся политике «расказачивания». Когда белые войска в мае 1919 г. вновь начали наступление, большевики решили мобилизовать этих казаков, пока их не мобилизовали белые. Мобилизация прикрывалась авторитетом Ф.К. Миронова, очень известного красного казака, в прошлом казачьего офицера, который в это время командовал советской Белорусско-Литовской армией. Было мобилизовано более 5 тысяч человек. Часть мобилизованных казаков была направлена в Белорусско-Литовскую армию, где из них успели создать два казачьих полка. Однако Ф.К. Миронов к тому времени получил новое назначение. Казаки, остав궁 шиеся в рядах Белорусско-Литовской армии, оказались в непривычных и тяжелых условиях. В ходе боевых ๓ं действий они попали в еврейские населенные пункты. Когда поляки начали наступление, наиболее боеспособные донские казаки из числа мобилизованных всем полком перешли на польскую сторону. Второй каза\%ै чий полк был разоружен советским командованием и отправлен в распоряжение Ф.К. Миронова. Формируемы Ф.К. Мироновым в Саранске из другой части мобилизованных казаков Донской корпус в августе (C) 191 1919 г. взбунтовался. Опыт показал, что при создании красных казачьих частей большевикам следовало опи-
\end{abstract}


раться на немногочисленных добровольцев и перебежчиков. Мобилизованные принудительно казаки были ненадежны, переходили к противнику.

Ключевые слова: казаки, поляки, Ф.К. Миронов, мобилизация, Белорусско-Литовская армия.

Цитирование. Венков А. В. Донские казаки на польском фронте в 1919 году // Вестник Волгоградского государственного университета. Серия 4, История. Регионоведение. Международные отношения. - 2017. T. 22, № 6. - C. 99-109. - DOI: https://doi.org/10.15688/jvolsu4.2017.6.10

В отечественной и зарубежной историографии гражданской войны большое внимание уделялось колебаниям значительной прослойки казаков, имевшим место на Дону [7] и выразившимся в таких знаковых событиях, как Вёшенское восстание [3] и мятеж корпуса Ф.К. Миронова. Особое внимание привлекал образ выразителя интересов этой прослойки казаков - Ф.К. Миронова, казачьего революционера, достигшего высших командных постов в Красной армии, репрессированного в 1921 г. и реабилитированного в 1960-м. Ф.К. Миронову были посвящены публицистические [14] и научно-популярные работы [15], наиболее полный материал о нем был собран в сборнике «Филипп Миронов. Тихий Дон в 1917-1921 гг.» [32].

После разгрома Добровольческой и Донской армий весной 1920 г. и мобилизации значительной части сдавшихся казаков в Красную армию указанные колебания не прекратились и проявились в переходах казаков из Красной армии к полякам в 1920 году. Казаки, перешедшие к полякам, сражались против Красной армии. Данные факты отражены в воспоминаниях С.М. Буденного [2, с. 210], дневниках писателя И. Бабеля. Например, запись от 31 августа 1920 г.: «Наш эскадрон идет в атаку. Скачем версты четыре. Они колоннами ждут нас на холме. Чудо - никто не пошевелился. Выдержка, дисциплина. Офицер с черной бородой... Бегство. Военкомы заворачивают. Ничего не помогает. К счастью, они не преследуют, иначе была бы катастрофа» [1, с. 199]. Исследовательские работы по указанным событиям созданы польскими историками [11].

Предлагаемая статья рассматривает событие, относящееся к двум обозначенным направлениям, - переход казаков, мобилизованных по инициативе Ф.К. Миронова, на сторону поляков еще летом 1919 г., в разгар гражданской войны на Дону.

Цель данной работы выяснить, насколько действенной была роль конкретной лично- сти (Ф.К. Миронова) в политическом выборе значительной части донских казаков в 1919 г. и какие другие факторы имели значение в этом выборе.

Ф.К. Миронов стремился опереться на казачьи массы в борьбе с контрреволюцией на Дону и использовал для своей цели самые разные средства. 23 июня 1918 г. Ф.К. Миронов призывал казаков самих разгромить контрреволюцию, пока не пришла Красная армия и не покарала без разбора правых и виноватых: «Опомнитесь же, казаки, не пускайте в свой округ чужих людей бороться с кадецко-немецко-казацкими контрреволюционными бандами, а берите борьбу в свои руки...» [5, л. 72]. Тот же Ф.К. Миронов писал в Реввоенсовет Республики, что «лучше заняться революционным казакоманством, чем эту работу предоставить Краснову» [18, л. 106].

Талантливый полководец и организатор Ф.К. Миронов прекрасно знал и использовал психологию казачьей массы и, проводя политику «революционного казакоманства», снискал себе авторитет «заступника казачества» и огромную популярность у казаков, красных и белых, вплоть до создания песни «Шумел, горел пожар над Доном» (вольная переработка «Пожара Московского», где образ Наполеона был заменен образом Ф.К. Миронова). «Наш товарищ Миронов плачет и жалеет о казаках, что они затуманены Красновым. Он всех прощает нас во всем», - писали пленные белые казаки в свои станицы $[17$, л. 1]. Посетивший в 1919 г. мироновские войска член Казачьего отдела ВЦИК Козюбердин высказал мнение, что «Миронов есть тревожно мятущаяся душа огромной численности среднего крестьянства и казачества» [9, л. 347-348].

В 1918 г. Миронов сформировал целую дивизию сторонников советской власти, в состав которой входила конная казачья бригада из казаков бывших 15-го и 32-го Донских полков старой царской армии, однако костяк ее составляли крестьяне и иногородние Хоперс- 
кого и Усть-Медведицкого округов [4, с. 237]. Во время наступления Южного фронта зимой 1918-1919 гг. и разложения белой Донской армии, казаки которой полками расходились по домам, у Ф.К. Миронова возникла идея сформировать в Красной армии еще одну конную казачью дивизию. С этим предложением он обратился в Реввоенсовет Республики и получил положительный ответ. 15 марта 1919 г. Реввоенсовет предложил Миронову «сформировать казачью дивизию на началах, которые установлены товарищем Мироновым в докладной записке» [27, л. 21].

Однако приступить к формированию дивизии не удалось. Сразу же за решением Реввоенсовета Республики последовал новый приказ о переводе Ф.К. Миронова помощником командующего Литовско-Белорусской армией. Дело в том, что стало известно о начале Вёшенского мятежа, который, как писали советские исследователи, был «вызван колебаниями середняцкой массы казачества, сословными предрассудками, а также ошибками советских органов в отношении казачества» [8, с. 91]. Разуверившиеся в красновском режиме и пытавшиеся встать на позиции нейтралитета казаки Верхнего Дона не выдержали принесенной большевиками политики военного коммунизма и расказачивания и восстали.

Ф.К. Миронов резко выступал против проводимой на Дону политики расказачивания, сулил неисчислимые беды от нее и, невзирая на лица, критиковал присланных на Дон руководителей, сторонников и проводников этой политики. Руководство Реввоенсовета Республики сочло выступления бывшего казачьего офицера Миронова в этот момент тревожным симптомом и перевело его на Западный фронт. «Мы его удалили с Дона, не вполне доверяя ему», - заявил впоследствии председатель РВСР Л.Д. Троцкий [16, с. 1].

Миронов уехал в Смоленск, а на Верхнем Дону распространилось казачье восстание, которое никак не удавалось подавить и которое много способствовало срыву наступления советского Южного фронта и переходу в наступление Вооруженных сил Юга России во главе с А.И. Деникиным.

Разошедшиеся по домам казаки Хоперского и Усть-Медведицкого округов все еще колебались. Незначительная часть их созда- ла дружины и вместе с частями Красной армии дралась против вёшенских повстанцев. Большинство сохраняло нейтралитет или ожидало прихода белых.

Большевистское руководство приняло решение мобилизовать колеблющихся казаков севера области, пока этого не сделали перешедшие в наступление деникинцы. Казачий Отдел ВЦИК поставил вопрос о необходимости этой мобилизации еще 25 апреля 1919 года. Однако постановление РВСР о мобилизации казаков на Севере Дона вышло лишь 26 мая, когда обстановка на Южном фронте резко ухудшилась. Первым днем мобилизации объявлялось 15 июня, последним 22 июня [24, л. 25].

Впоследствии советские органы признавали, что мобилизованные казаки пошли на сборные пункты не из-за симпатий к советской власти, а «скорее убоялись гражданской войны на своей земле» $[9$, л. 177].

Так как мобилизуемые казаки колебались и в Красную армию шли неохотно, решено было вновь использовать популярность Миронова. Главнокомандующий Вооруженными силами Республики И.И. Вацетис сообщил 29 мая на Южный фронт, что цель мобилизации сводится к формированию одной кавалерийской дивизии из донских казаков, а общее руководство формированием возлагается на командующего Белорусско-Литовской армией Ф.К. Миронова, к которому в район Смоленска и надлежит направлять всех мобилизованных казаков «с лошадьми и обмундированием, но безоружных» [24, л. 25].

Штаб казачьей дивизии Миронову было предложено сформировать в районе Белорусско-Литовской армии и, соответственно, за счет местных сил [24, л. 25].

Белорусско-Литовская армия, с 9 июня 1919 г. переименованная в 16-ю армию, вела бои против польских войск. В марте-апреле поляки наступали, но в мае после неудачных для большевиков боев за Вильно установилось относительное затишье.

Узнав, что его вновь назначили формировать казачью дивизию, Ф.К. Миронов немедленно, 30 мая, направил в штаб Южного фронта конкретные предложения по мобилизации, где до деталей расписал все, вплоть до того, где взять седла и пики, а где фураж для лоша- 
дей мобилизованных [24, л. 26]. Кроме того, Миронов предложил командный состав дивизии сформировать на Дону из лично известных ему людей. На должность командира дивизии он предлагал Голикова или Сдобнова, а командирами полков предлагал казаков Слышкина, Мироничева, Карпова, Блинова, Кувшинова, Корнеева, Мазлова, Буянова. А.Г. Голиков в это время командовал 23-й стрелковой дивизией, созданной Ф.К. Мироновым в 1918 г. из донских крестьян и казаков. И.А. Сдобнов был в этой дивизии начальником штаба. И.Н. Карпов и А.Ф. Мироничев командовали в ней полками. Из других названных Ф.К. Мироновым казаков особую популярность впоследствии приобрел командир полка, а затем дивизии М.Ф. Блинов, именем которого в 1920 г. была названа 2-я Кавалерийская дивизия Красной армии.

31 мая формирование дивизии официально началось. Предполагалось, что состав ее будет более 4 тысяч человек [24, л. 35]. В тот же день Миронов своей волей направил приглашение А.Г. Голикову принять командование формируемой дивизией [24, л. 41$]$.

2 июня он обратился к мобилизованным с воззванием «В добрый час, донцы!». Некоторые казаки, узнав о воззвании Миронова, добровольно отправились к нему в Смоленск, не дожидаясь указанного в повестках срока, зато отдельные станицы Хоперского округа, прослышав о мобилизации, наоборот, взбунтовались и стали переходить к вёшенским повстанцам.

В специальном рапорте Миронов просил направить его на две недели на Дон, чтобы помочь с мобилизацией. «Да и по словам только что прибывших казаков с Дона, присутствие мое для целей формирования было бы крайне желательно», - писал он в рапорте [24, л. 28 об.].

Однако ситуация на Западном фронте не позволяла Миронову отлучиться. Более того, когда мобилизационная комиссия потребовала от Миронова прислать для приемки мобилизованных 450 красноармейцев (по 1 на 10 мобилизованных), тот 4 июня ответил, что выслать такое количество бойцов он не может, так как идут бои [31, л. 1]. Действительно, 2728 мая советские войска начали неудачное наступление на Вильно.
И все же Ф.К. Миронова послали на Дон не на время и не для проведения мобилизации. Объединение вёшенских повстанцев с регулярной белоказачьей конницей поставило ситуацию на Южном фронте на грань катастрофы. 10 июня 1919 г. член Реввоенсовета Южного фронта Г.Я. Сокольников поставил перед Реввоенсоветом Республики вопрос о назначении Миронова командующим Особым корпусом, действующим против вёшенских повстанцев. «Состав войск гарантирует против отклонения от советской линии, имя Миронова обеспечит нейтралитет и поддержку северных округов, если не поздно», - писал Г.Я. Сокольников Л.Д. Троцкому [13, л. 47].

14 июня Миронов сдал командование армией и выехал из Смоленска на Дон. На следующий день, 15 июня, навстречу ему, с Дона на Западный фронт, были высланы первые эшелоны мобилизованных казаков Урюпинской станицы.

Даже появление на Южном фронте такой личности, как Миронов, не помогло Красной армии удержать Донскую область. Сведенная в корпуса белоказачья конница, широко применяя рейды, обходы и другие приемы, присущие крупным кавалерийским массам, ворвалась на территорию Воронежской и Саратовской губерний. Белой коннице надо было противопоставить конницу красную. «Вопрос о создании боеспособной кавалерии является важнейшим вопросом Южного фронта», - напоминал Реввоенсовет Республики 13 июня [28, л. 171]. 29 июня Реввоенсовет Южного фронта обратился к комкору Особого Миронову с вопросом о возможности сформирования «крупного и правильного кавалерийского соединения» из кавалерии его корпуса и из мобилизованных казаков, которых не успели еще направить на Западный фронт [28, л. 283].

Миронов предложил Реввоенсовету сформировать конный корпус из донских казаков, бежавших от власти Деникина и мобилизованных советскими органами в мае июне 1919 года. 1 июля предложение Миронова было направлено на рассмотрение главкому Вацетису. Тот передал решение на усмотрение Реввоенсовета Южного фронта. 5 июля 1919 г. приказом № 1094 на Миронова было возложено формирование Донского казачьего корпуса из двух конных казачьих ди- 
визий и бригады пехоты из донских крестьян [27, л. 187]. 8 июля на приеме у В.И. Ленина Миронов обещал сформировать корпус к 15 августа 1919 года [12, л. 18]. Так было положено начало событиям, которые впоследствии вошли в историю гражданской войны под названием «мятеж Миронова».

Мобилизованные казаки (таковых удалось собрать до 5,5 тысяч) [6, с. 70] отныне направлялись в Саранск на формирование Донского казачьего корпуса.

На укомплектование корпуса также решено было направить казаков, ранее посланных на Западный фронт. Судьба их сложилась печально.

23 июня 1919 г. 1253 казака при 731 лошади прибыли в район г. Борисова под Смоленском, но Миронова, который, как им было объявлено, должен был формировать из них дивизию, на Западном фронте уже не было. Bce без исключения прибывшие были казаками. Комсостав тоже состоял из казаков, которые в царской армии были взводными командирами, в революционное время командовали сотнями. Некоторые из мобилизованных успели послужить в Красной армии. Отмечалось, что настроение прибывших бодpoe [22, л. 35]. Довольно высок был и уровень грамотности. На весь 2-й полк оказалось всего 56 неграмотных [23, л. 29 об.], а в политсводках упоминалось, что казаки охотно пользуются политотдельской библиотекой [21, л. 12 об.].

Самовольное приглашение Ф.К. Мироновым на должность командира дивизии А.Г. Голикова не имело последствий. Командовать дивизией был назначен П.М. Боревич, польский интернационалист, служивший до этого в 1-й армии на Восточном фронте. Военным комиссаром дивизии стал К.А. Жгун, заведующим политотделом, созданным довольно поздно - 30 июня, - В. Андреев. Дивизии даже было присвоено название «3-я казачья» $[21$, л. 1]. Дело в том, что в состав 16-й армии входили всего две дивизии - Западная стрелковая, состоявшая из польских интернационалистов, и 17-я стрелковая, включавшая в себя бывшие 1-ю Витебскую и 2-ю Смоленскую дивизии.

Из прибывших казаков можно было сформировать бригаду в два полка. Бригаду возглавил «красный академик» (закончивший военную академию уже при Советской власти) Измайлов. Казаков, прибывших со своими лошадьми, свели в 1-й полк, остальных во 2-й, отделив тем самым зажиточных и середняков от бедноты. Во главе 1-го полка был поставлен бывший ротмистр, во главе 2-го урядник. Оставалось ждать следующей партии мобилизованных, чтобы создать вторую бригаду и свести две бригады в полнокровную конную дивизию.

Однако приток пополнений с Дона прекратился, мобилизованные теперь направлялись в Саранск. Из казаков, прибывших на Западный фронт, решили формировать не дивизию, а отдельную бригаду. 10 июля врид командира бригады Измайлов ввиду переформирования дивизии в бригаду был назначен командиром 2-го полка, сменив бывшего урядника. П.М. Боревич, соответственно, из командира дивизии превратился в командира бригады, а 14 июля и вовсе сдал командование А.А. Дмуховскому [25, л. 10].

Бодрое настроение прибывших скоро сменилось унынием. Политработники объясняли это тем, что казаки «прибыли в голодный центр с хороших вольных хлебов» [21, л. 57]. Мобилизованные по 2-3 дня не видели хлеба. Обмундирование тоже оставляло желать лучшего. Продовольственная комиссия не имела нужных денежных сумм [22, л. 6]. Вдобавок ко всему в бригаде открылась эпидемия сыпного тифа [22, л. 6].

Местные политработники сразу же проявили настороженность, отмечая, что среди прибывших казаков много кулаков [22, л. 1], и вообще по своему экономическому положению казаки «представляют противоположность крестьянам центральных губерний» [21, л. 58 об]. Прибывшие на Западный фронт казаки тоже держали себя крайне настороженно. Причиной была политика, проводимая советской властью на родине мобилизованных. Политработники тех мест, куда прибывали мобилизованные казаки, докладывали: после того, что «проделывали на местах власти, именующие себя коммунистами», у мобилизованных «вообще взгляд на коммуниста, как на злейшего врага» $[30$, л. 5]. Во 2-м полку «во всех частных беседах казаки высказывали большое недовольство своими местны- 
ми властями, сильно реагируя на расстрелы, которые, по-видимому, практиковались в самых широких размерах не только по отношению к донской буржуазии, но и по отношению к трудовому казачеству» [21, л. 58]. Но и по поводу местных политработников казаки тоже говорили, что они приезжают в сотни «шпионить и зря болтать» [22, л. 7 об.].

Масла в огонь подлили прибывшие вместе с казаками на Западный фронт донские коммунисты, которые казакам не доверяли и которых казаки ненавидели. 26 июня в бригаду прибыл из Урюпинской станицы, с родины мобилизованных казаков, комиссар Тюменков. Тюменков запретил организовывать в 1-м полку коммунистическую ячейку, «чтобы не проникли шпионы» [26, л. 2]. Впрочем, в политсводке от 13 июля 1919 г. говорится, что 9 июля в 1-м полку все же проводилось партийное собрание [21, л. 21].

Во 2-м полку, где были собраны казаки победнее, донские коммунисты Синякин и Горлов стали организовывать ячейку. Казаки на политзанятиях не соглашались с идеями коммунистов и апеллировали к авторитету Ф.К. Миронова, который в 1918 г. называл себя левым эсером [19, л. 21 об.] и эсероммаксималистом, то есть - крестьянским революционером: «Почему вы нам всегда об этом толкуете и говорите, а Миронов нам об этом ничего не говорит?» В ответ в своей агитационной работе коммунисты старались подорвать авторитет Ф.К. Миронова, благодаря которому, собственно, казаки пошли на мобилизационные пункты. Они «объясняли, что Миронов не коммунист и не большевик, а он капиталист, потому что у него много находится земли и имения. Оттого он не желает записаться в партию» $[22$, л. 1]. Это было ложью. Казаки прекрасно знали, что Миронов происходит из простой казачьей семьи и службу начинал рядовым казаком. Все это не способствовало авторитету коммунистов, и в ячейку, как отмечали Синякин и Горлов, записалось «очень мало» $[22$, л. 1]. На 8 июля в ячейке 2-го полка числилось 6 членов [21, л. 11].

Агитационная работа в 1-м полку больших результатов тоже не дала. 2 июля на собрании казаки демонстративно задавали вопросы о событиях на Дону, о самочинных обысках, о постоянных угрозах расстрелом. При этом они говорили: «Если б у нас на Дону были работники, которые бы защищали трудящихся, то весь Дон бы [все донские казаки] были большевики». После ухода агитаторов несколько казаков порвали портрет Ленина, но другие отнеслись к этому «печально» [26, л. 1].

Как отмечалось в политсводках, казаки все время интересовались положением на Южном фронте, то есть тем, что творилось у них дома [21, л. 58].

Политработники сообщали, что настроение в полку испортилось из-за обмундирования, вернее, из-за отсутствия оного. По этому поводу среди казаков начались антисоветские разговоры, и три казака - Толкованов, Боков и Сивогривов - были убраны из полка за агитацию [26, л. 6].

1 июля 1919 г. польское командование развернуло новое наступление, стремясь занять Минск, Борисов, Бобруйск и выйти на p. Березину - удобный рубеж для обороны почти под стенами Смоленска.

В первый же день боев легионеры взяли с боем станцию Вилейку. Основной удар был направлен на железнодорожный узел Молодечно (20 км южнее Вилейки) и далее - на Минск. 4 июля польские войска заняли Молодечно.

Чтобы остановить поляков на этом направлении, нужны были свежие силы. 5 июля 1919 г. прибывший по мобилизации на своих лошадях 1-й полк (командир Мосесов, комиссар Олдак), имея в строю 450 казаков, был послан в Борисов и далее на линию фронта. Перед отправкой местные политработники провели митинг и отметили, что казаки слушали все речи «с напряженным вниманием» [22, л. 15].

Полк выступил далеко не в полном составе. Казаки, имеющие лошадей, но не имеющие седел, а таковых набралось 51 , остались со 2-м полком, вообще не имевшим лошадей.

Путь от Борисова до линии фронта был неблизкий, и на марше решались не решенные во время формирования проблемы. Так, 10 июля комиссар полка Олдак срочно запросил обмундирование, и 13 июля политсводка сообщила, что «в связи с получением полком обмундирования настроение казаков вполне удовлетворительное», недовольны только тем, что вместо сапог получили ботинки [21, л. 21]. 
Сведений об участии 1-го полка в боях не обнаружено, но известно, что от Молодечно советские войска были отбиты.

15 июля 1-й полк находился в прикрытом с запада болотами местечке Плещеницы. До войны на всю Беларусь была известна пословица: «В Беларуси три столицы - Минск, Бобруйск и Плещеницы». Имелось в виду, что в Плещеницах и в его окрестных местечках (Хатаевичи, Околово, Крайск, Долгиново) проживало в то время не меньше евреев, чем в Бобруйске и Минске, где их в процентном соотношении было больше всего в Беларуси. Так, к примеру, в 1897 г. в Плещеницах еврейское население составляло 82 \% [20]. В политсводке было сообщение, что во время отступления казаки грабили население и меняли лошадей - оставляли местным жителям своих обессилевших, а у них забирали свежих [22, л. 10].

На 17 июля 16-я армия готовила контрнаступление на Вилейку. 16 июля 1-й казачий полк снова выступил на позиции, двинулся на северозапад от Плещениц, как раз в сторону Вилейки. 17-го наступление началось, советские войска, прорвав польский фронт, продвинулись с боями на 40 км. Но в тот же день, 17 июля, 1-й полк в селении Крайск, на берегу речки Вилия, разбил две бакалейные лавки [23, л. 33 об.]. И это было последнее известие из полка.

Затем, в ночь на 20 июля, появились тревожные слухи. Снабженцы, повезшие в полк хлеб, встретили командира полка и 5 казаков, которые сказали им, что полк сдался. Не ушли к полякам всего 20 казаков [22, л. 10 об.]. Политработники пытались выяснить обстоятельства сдачи и узнали, что к казакам 1-го полка приходили красноармейцы и вели пропаганду против войны [21, л. 23]. Возможно, это были поляки из Западной стрелковой дивизии, поскольку 17-я стрелковая дивизия вела бои гораздо южнее указанной территории.

Польские источники подтверждают: ночью с 17 на 18 июля 1919 г. на сторону поляков перешел казачий полк атамана Лазарева в количестве 620 всадников, потом этот полк поляки якобы отправили к Деникину [29]. Деникин в своих «Очерках русской смуты» не упоминает об отправке ему союзниками-поляками полка казаков. Сами контакты между
Деникиным и польским командованием были установлены лишь в сентябре 1919 г., а между деникинскими и польскими войсками на всем протяжении гражданской войны находились либо петлюровцы, либо советские войска. Видимо, эти казаки были интернированы, а к белым попали уже в 1920 г., когда из Польши в Крым через Румынию перебрасывались значительные контингенты пленных и интернированных, пожелавших сражаться в рядах армии Врангеля.

Незначительная часть казаков осталась служить у поляков. В польских источниках есть комментарий к одной из фронтовых фотографий: «Взвод подпоручика Гасовского из 7-го уланского полка форсирует реку Рабчанка (?) вместе со взводом донских казаков, которые сдались в плен полякам в Сосенчах (?) около Вязыня (?). Фотография сделана в 1919 г. во время летнего наступления на литовско-белорусском фронте» [10].

«Рабчанка» - это речка Рыбчанка, которая образуется от слияния рек Вязынка и Гуйка в пределах Нарочанско-Вилейской низменности у поселка Радошковичи.

Что касается места перехода казаков к полякам, то Вязынь - это селение, которое находится на равном расстоянии от Вилейки и от Молодечно в 30 км от Крайска, где донцы отметились своим последним грабежом. В настоящее время Вязынь отделена от Крайска искусственным водохранилищем. «Сосенчи» определить не удалось.

В целом операция закончилась тем, что поляки, располагая неизмеримо большими силами и подтянув подкрепления, отбросили оба фланга 16-й армии и стали охватывать Минский район.

После ухода 1-го полка к полякам стал стремительно разлагаться 2-й полк, остававшийся в Могилеве. Ухудшились отношения казаков с местным населением. Казаки начали рыть картофель у крестьян. Когда по этому поводу в полку провели собрание, казаки стали жаловаться на нехватку продовольствия и невыдачу жалования [21, л. 22].

Комиссар полка 20 июля доносил: «По отношению к Советской власти полк может считаться нелояльным. Есть предположение, что в случае отправки на фронт, полк имеет намерение перейти к неприятелю» [21, л. 23]. 
Предположение подтвердилось. Вскоре казак Майнин сообщил комиссару полка А. Медведеву, что 2-й полк тоже собирается в плен [23, л. 27]. И комиссар в сводке от 24 июля отметил, ссылаясь на Майнина: «В частных разговорах казаки выражают желание скорее отправиться на фронт, но это желание сводится к тому, чтобы при первом удобном случае перейти в плен» [21, л. 30].

Все это происходило на фоне польского наступления. В Борисове, Полоцке, Бобруйске и Мозыре спешно готовились узлы обороны. Польские войска стремились обойти Минск с севера. В таких условиях держать в Могилеве полк казаков, готовых уйти к полякам, было крайне опасно.

В конечном итоге всех казаков, и вернувшихся, и тех, кто не уходил, разоружили, отобрали лошадей, после чего направили в Саранск к Миронову, где они составили 2-й Донской казачий полк в формируемом Донском казачьем корпусе. Управление бригады к 29 июля расформировали. Перевод казаков из Белоруссии в Особый Донской корпус не разрешил противоречий. Вскоре корпус, возглавляемый Ф.К. Мироновым, взбунтовался, что уже было предметом ряда специальных исследований.

Таким образом, советские казачьи части в 1918-1919 гг. были малочисленны и создавались из добровольцев и перебежчиков. Даже на Севере Дона, где в 1918 г. удалось создать целые полки из казаков, массовая мобилизация казаков в Красную армию по территориальному принципу в 1919 г. имела описанные выше последствия.

События проходили на фоне политики расказачивания, что вызывало среди казаков северных округов Дона либо колебания, либо открытое неприятие советской власти. Казаки согласились на мобилизацию в Красную армию и отправку на Западный фронт, стараясь избежать мобилизации в белую армию и участия в гражданской войне на родине (между казаками). Однако в своих мыслях они постоянно обращались к ситуации на Дону.

Ф.К. Миронов стремился сделать казаков не только военной, но и самостоятельной просоветской политической силой, и казаки на Севере Дона в какой-то мере поддерживали это. Большевики же стремились использовать казаков как силу чисто военную и вырвать их из-под влияния Ф.К. Миронова.

Когда казаки попали в ряды Красной армии без перспектив создания мощной чисто казачьей воинской части, когда большевики стали подрывать авторитет Ф.К. Миронова, отношение мобилизованных к большевикам еще больше ухудшилось.

Местные белорусские большевики настороженно относились к прибывшим казакам, отмечая отличие их экономического положения от местных крестьян. Сами условия жизни на рассматриваемой территории были для казаков непривычны, оказались более тяжелыми, чем на Дону.

Определенную роль сыграло то, что казаки оказались на фронте, где друг с другом воевали поляки (польская армия и Западная дивизия Красной армии, состоявшая в большинстве из поляков), и размещались в еврейских местечках. Эта война была для них непонятна и чужда.

Из перешедшего к полякам полка казаков упоминается лишь один взвод, принявший участие в борьбе против большевиков. Переход полка к полякам был попыткой выйти из войны, оказаться в плену. Большевистское руководство им такой возможности не дало бы.

\section{СПИСОК ЛИТЕРАТУРЫ}

1. Бабель, И. Э. Конармия. Рассказы, дневники, публицистика / И. Э. Бабель. - М. : Правда, 1990. $-480 \mathrm{c}$.

2. Буденный, С. М. Пройденный путь. Кн. 2 / С. М. Буденный. - М. : Воениздат, 1965. - 392 с.

3. Венков, А. В. Вёшенское восстание / А. В. Венков. - М. : Вече, 2016. $-352 \mathrm{c}$.

4. Венков, А. В. «Трижды окруженный и разбитый наголову» Филипп Миронов // Донской временник. 2013. - Ростов н/Д, 2012. - С. 236-241.

5. Воззвание Ф.К. Миронова к казакам УстьМедведицкого округа // Российский государственный военный архив (РГВА). -Ф. 1304. -Оп. 1. - Д. 478.

6. Воскобойников, Г. Л. Борьба партии за трудовое казачество / Г. Л. Воскобойников, Д. К. Прилепский. - Грозный : Чеч.-Ингуш. кн. изд-во, 1980. - 151 с.

7. Голдин, В. И. Россия в Гражданской войне. Очерки новейшей историографии (вторая половина 1980-х - 90-егоды) / В. И. Голдин. - Архангельск : Боргес, 2000. -280 c.

8. Гражданская война и военная интервенция в СССР : Энциклопедия. -М. : Сов. энцикл., 1983. - 704 с. 
9. Доклад тов. Козюбердина об инспекции Донского корпуса Ф.К. Миронова // Государственный архив Российской Федерации (ГАРФ). Ф. 1235. - Оп. 82. - Д. 15.

10. Казаки на стороне поляков. 1920. Ч. 1. Электрон. текстовые дан. - Режим доступа: http:// hetmanec.livejournal.com/11201.html (дата обращения: 30.08.2017). - Загл. с экрана.

11. Карпус, Збигнев. Казачьи формирования, созданные в Польше (июнь - ноябрь 1920 г.) и их участие в Советско-Польской войне // Kawaleria Przeciwnikyw i Sojusznikyw Wojska Polskiego w Latach 1918-1921/ pod redakcj Aleksandra Smolicskiego. - Toruc : Wyd-wo Uniwersytetu M. Kopernikac, 2003. - Электрон. текстовые дан. Режим доступа: http://beloe-dvijenie.livejournal.com/ 537965.html (дата обращения: 30.08.2017). - Загл. с экрана.

12. Копия письма Ф.К. Миронова к В.И. Ленину // Центр документации новейшей истории Ростовской области (ЦДНИРО). - Ф. 910. - Оп. 3. - Д. 752.

13. Копия письма члена РВС Южного фронта Г.Я. Сокольникова председателю РВСР Л.Д. Троцкому // ЦДНИРО. - Ф. 910. - Оп. 3. - Д. 665.

14. Лосев, Е. Ф. Миронов / Е. Ф. Лосев. - М. : Мол. гвардия, 1991. -430 с.

15. Медведев, Р. Жизнь и гибель Филиппа Кузьмича Миронова / Р. Медведев, С. Стариков. - М. : Патриот, 1989. - 366 с.

16. Общегородская конференция Московской организации РКП. Речь товарища Троцкого // Известия ВЦИК. - 1919. - № 214. - 26 сент.

17. Письмо пленных казаков своим станичникам // РГВА. - Ф. 192. - Оп. 2. - Д. 4.

18. Письмо Ф.К. Миронова в РВС Республики // РГВА. -Ф. 1304. - Оп. 1. - Д. 489.

19. Письмо Ф.К. Миронова в ЦИК Донской республики // Государственный архив Ростовской области (ГАРО). - Ф. 4071. - Оп. 2. - Д. 10.

20. Плещеницы.ру. Новости из центра Беларуси. - Электрон. текстовые дан. - Режим доступа: http://pleschenitsy.by/news/pleschenitsy/1081-ubelarusi-try-stalicy-minsk-babruisk-i-pleschanicy (дата обращения: 30.08.2017). - Загл. с экрана.

21. Политические сводки политотдела отдельной казачьей бригады 16-й армии // РГВА. Ф. 7875. -Оп. 1. - Д. 1.

22. Политические сводки политотдела отдельной казачьей бригады 16-й армии // РГВА. Ф. 7875. - Оп. 1. - Д. 5.

23. Политические сводки политотдела отдельной казачьей бригады 16-й армии // РГВА. Ф. 7875. -Оп. 1. - Д. 7.

24. Приказание главнокомандующего Вооруженными силами Республики И.И. Вацетиса командующему войсками Южного фронта; отношение
Ф.К. Миронова в РВС Южного фронта // РГВА. Ф. 7875. - Оп. 1. - Д. 15.

25. Приказ по штабу отдельной казачьей бригады 16-й армии // РГВА. - Ф. 7875. - Оп. 1. - Д. 18.

26. Рапорт политического комиссара 1-го Донского полка отдельной казачьей бригады 16-й армии // РГВА. -Ф. 7875. - Оп. 1. - Д. 6.

27. Распоряжение полевого штаба РВС Республики; приказ РВС Южного фронта № 1094 от 05.07.1919// РГВА. - Ф. 6. - Оп. 5. - Д. 188.

28. Распоряжение РВС Республики о подготовке к формированию кавалерийских частей на Южном фронте; запрос РВС Южного фронта к командующему Особым корпусом Ф.К. Миронову // РГВА. -Ф. 100. - Оп. 3. - Д. 967.

29. Русские белогвардейцы в Польше. 1920. Электрон. текстовые дан. - Режим доступа: http:// voencomuezd.livejournal.com/591967.html. - Загл. с экрана.

30. Сводка политотдела Донского казачьего корпуса // РГВА. - Ф. 7607. - Оп. 1. - Д. 2.

31. Телеграмма Ф.К. Миронова в штаб Южного фронта // РГВА. - Ф. 7875. - Оп. 1. - Д. 16.

32. Филипп Миронов. Тихий Дон в 19171921 гг. Документы и материалы. - М. : Фонд «Демократия», 1997. - 792 с.

\section{REFERENCES}

1. Babel I.E. Konarmiya. Rasskazy, dnevniki, publitsistika. [The Red Cavalry. Stories, Diaries, Articles]. Moscow, Pravda Publ., 1990. 480 p.

2. Budennyy S. M. Proydennyy put. Ch. 2 [The Traversed Path. Part 2]. Moscow, Voenizdat Publ., 1965. $392 \mathrm{p}$.

3. Venkov A.V. Veshenskoe vosstanie [Veshensk Rebellion]. Moscow, Veche Publ., 2016. 352 p.

4. Venkov A.V. «Trizhdy okruzhennyy i razbityy nagolovu» Filipp Mironov ["Three Times Surrounded and Smashed to Pieces" Filipp Mironov]. Donskoy vremennik. 2013 [Don Annals. 2013]. Rostov-on-Don, 2012, pp. 236-241.

5. Vozzvanie F.K. Mironova k kazakam UstMedveditskogo okruga [The Appeal of F.K. Mironov to Cossacks of the Ust-Medveditsky District]. Rossiyskiy Gosudarstvennyy voennyy arkhiv [Russian State Military Archive], F. 1304, Op. 1, D. 478.

6. Voskoboynikov G.L., Prilepskiy D.K. Borba partii za trudovoe kazachestvo [Party's Struggle for the Working Cossacks]. Grozny, Chech.-Ing. kn. izd-vo, 1980. 151 p.

7. Goldin V.I. Rossiya v Grazhdanskoy voyne. Ocherki noveyshey istoriografii (vtoraya polovina 1980-kh-90-e gody) [Russia in the Civil War. Essays on Modern Historiography (Second Half of the 1980s 1990s)]. Arkhangelsk, Borges Publ., 2000. 280 p. 
8. Grazhdanskaya voyna $i$ voennaya interventsiya $v$ SSSR. Entsiklopediya [Civil War and Military Intervention in the USSR. Encyclopedia]. Moscow, Sov. entsikl. Publ., 1983. 704 p.

9. Doklad tov. Kozyuberdina ob inspektsii Donskogo korpusa F.K. Mironova [The Report of Comrade Kozyuberdin about the Inspection of the Don Corps of F. K. Mironov]. Gosudarstvennyy arkhiv Rossiyskoy Federatsii [State Archive of the Russian Federation], F. 1235, Op. 82, D. 15.

10. Kazaki na storone polyakov. 1920. Chast 1 [The Cossacks on the Side of the Poles. 1920. Part 1]. URL: http://hetmanec.livejournal.com/11201.html. (accessed September 5, 2017)

11. Zbigniew K. Kazachyi formirovaniya, sozdannye v Polshe (iyun - noyabr 1920 g.) i ikh uchastie v Sovetsko-Polskoy voyne [Cossacks Troops in Poland (June-November 1920) and Their Participation in the Polish-Soviet War]. Smolisski A., ed. Kawaleria Przeciwnikuw i Sojusznikuw Wojska Polskiego w Latach 1918-1921. Torus, Wyd-wo Uniwersytetu M. Kopernikas, 2003.

12. Kopiya pisma F.K. Mironova k V.I. Leninu [A Copy of the Letter of F.K. Mironov to V.I. Lenin]. Tsentr dokumentatsii noveyshey istorii Rostovskoy oblasti [The Documentation Centre of Modern History in the Rostov Region], F. 910, Op. 3, D. 752.

13. Kopiya pisma chlena RVS Yuzhnogo fronta G.Ya. Sokolnikova predsedatelyu RVSR L.D. Trotskomu [A Copy of the Letter of Member of the RMS of the Southern Front G.Ya. Sokolnikov to Chairman of the Military Revolutionary Council of the Republic L.D. Trotsky]. Tsentr dokumentatsii noveyshey istorii Rostovskoy oblasti [The Documentation Centre of Modern History in the Rostov Region], F. 910, Op. 3, D. 665.

14. Losev E. F. Mironov [Mironov]. Moscow, Molodaya gvardiya Publ., 1991. $430 \mathrm{p}$.

15. Medvedev R., Starikov S. Zhizn i gibel Filippa Kuzmicha Mironova [The Life and Death of F.K. Mironov]. Moscow, Patriot Publ., 1989. 366 p.

16. Obshchegorodskaya konferentsiya Moskovskoy organizatsii RKP. Rech tovarishcha Trotskogo [City-Wide Conference of the Moscow Organization of the RCP. Speech of Comrade Trotsky]. Izvestiya VTsIK, 1919, no. 214, September 26.

17. Pismo plennykh kazakov svoim stanichnikam [The Letter of the Cossacks-Prisoners to Their Countrymen]. Rossiyskiy Gosudarstvennyy voennyy arkhiv [Russian State MilitaryArchive], F. 192, Op. 2, D. 4.

18. Pismo F.K. Mironova v RVS Respubliki [The Letter of F.K. Mironov to the RMS of the Republic]. Rossiyskiy Gosudarstvennyy voennyy arkhiv [Russian State Military Archive], F. 1304, Op. 1, D. 489.

19. Pismo F.K. Mironova v TsIK Donskoy respubliki [Letter of F.K. Mironov to the CEC of the
Don Republic]. Gosudarstvennyy arkhiv Rostovskoy oblasti [State Archive of the Rostov Region], F. 4071, Op. 2, D. 10.

20. Pleshchenitsy.ru. Novosti iz tsentra Belarusi [Pleshchenitsy.ru. News from the Centre of Belarus]. URL: http://pleschenitsy.by/news/pleschenitsy/1081u-belarusi-try-stalicy-minsk-babruisk-i-pleschanicy. (accessed September 4, 2017).

21. Politicheskie svodki politotdela otdelnoy kazachey brigady 16-y armii [Political Reports of the Political Department of the Separate Cossack Brigade of the $16^{\text {th }}$ Army]. Rossiyskiy Gosudarstvennyy voennyy arkhiv [Russian State Military Archive], F. 7875 , Op. 1, D. 1.

22. Politicheskie svodki politotdela otdelnoy kazachey brigady 16-y armii [Political Reports of the Political Department of the Separate Cossack Brigade of the $16^{\text {th }}$ Army]. Rossiyskiy Gosudarstvennyy voennyy arkhiv [Russian State Military Archive], F. 7875 , Op. 1, D. 5 .

23. Politicheskie svodki politotdela otdelnoy kazachey brigady 16-y armii [Political Reports of the Political Department of the Separate Cossack Brigade of the $16^{\text {th }}$ Army]. Rossiyskiy Gosudarstvennyy voennyy arkhiv [Russian State Military Archive], F. 7875 , Op. 1, D. 7.

24. Prikazanie glavnokomanduyushchego Vooruzhennymi silami Respubliki I.I. Vatsetisa komanduyushchemu voyskami Yuzhnogo fronta; otnoshenie F.K. Mironova v RVS Yuzhnogo fronta [The Order of Commander-in-Chief of the Armed Forces of the Republic I.I. Vatsetis to Commander of the Southern Front; Relation of F.K. Mironov to the RMS of the Southern Front]. Rossiyskiy Gosudarstvennyy voennyy arkhiv [Russian State Military Archive], F. 7875, Op. 1, D. 15.

25. Prikaz po shtabu otdelnoy kazachey brigady 16-y armii [The Order of the Headquarters of a Cossack Brigade of the $16^{\text {th }}$ Army]. Rossiyskiy Gosudarstvennyy voennyy arkhiv [Russian State Military Archive], F. 7875, Op. 1, D. 18.

26. Raport politicheskogo komissara 1-go Donskogo polka otdelnoy kazachey brigady 16 -y armii [The Report of Political Commissar of the $1^{\text {st }}$ Regiment of the Don Cossack Separate Brigade of the $16^{\text {th }}$ Army]. Rossiyskiy Gosudarstvennyy voennyy arkhiv [Russian State Military Archive], F. 7875, Op. 1, D. 6.

27. Rasporyazhenie polevogo shtaba RVS Respubliki; prikaz RVS Yuzhnogo fronta № 1094 ot 05.07.1919 [The Order of the Field Headquarters of the Revolutionary Military Council of the Republic; the Order of the RMC of the Southern Front no. 1094 of July 5, 1919]. Rossiyskiy Gosudarstvennyy voennyy arkhiv [Russian State Military Archive], F. 6, Op. 5, D. 188.

28. Rasporyazhenie RVS Respubliki o podgotovke $\mathrm{k}$ formirovaniyu kavaleriyskikh chastey 
na Yuzhnom fronte; zapros RVS Yuzhnogo fronta k komanduyushchemu Osobym korpusom F.K. Mironovu [The Decree of the Revolutionary Military Council of the Republic about the Preparation to the Formation of Cavalry Units at the Southern Front; the Query of RMC of the Southern Front to Commander of the Special Corps F.K. Mironov]. Rossiyskiy Gosudarstvennyy voennyy arkhiv [Russian State Military Archive], F. 100, Op. 3, D. 967.

29. Russkie belogvardeytsy v Polshe. 1920 [White Russians in Poland. 1920]. URL: http:// voencomuezd.livejournal.com/591967.htm. (accessed September 4, 2017).
30. Svodka politotdela Donskogo kazachyego korpusa [Summary of the Political Department of the Don Cossack Corps]. Rossiyskiy Gosudarstvennyy voennyy arkhiv [Russian State Military Archive], F. 7607, Op. 1, D. 2.

31. Telegramma F.K. Mironova v shtab Yuzhnogo fronta [The Telegram of F.K. Mironov to the Headquarters of the Southern Front]. Rossiyskiy Gosudarstvennyy voennyy arkhiv [Russian State Military Archive], F. 7875, Op. 1, D. 16.

32. Filipp Mironov. Tikhiy Don v 1917-1921 gg. Dokumenty i materialy [Philip Mironov. The Quiet Don in 1917-1921. Documents and Materials]. Moscow, Demokratiya Publ., 1997. 792 p.

\section{Information about the Author}

Andrey V. Venkov, Doctor of Sciences (History), Professor, Head of Cossacks Laboratory, Southern Scientific Center of Russian Academy of Sciences, Prosp. Chekhova, 41, 344006 Rostov-on-Don, Russian Federation, andrey_venk@rambler.ru, https://orcid.org/0000-0002-4455-2822

\section{Информация об авторе}

Андрей Вадимович Венков, доктор исторических наук, профессор, заведующий лабораторией казачества Южного научного центра Российской академии наук, просп. Чехова, 41, 344006 г. Ростовна-Дону, Российская Федерация, andrey_venk@rambler.ru, https://orcid.org/0000-0002-4455-2822 